perform clinics. Commonly we arrived late in the day and as the patients may already have been waiting for several hours, it was usual to get started straight away and work until everyone had been seen. Botswana's long summers are very hot, with temperatures over $40^{\circ} \mathrm{C}$ being common; the four-wheel drive trucks that we used did not have air-conditioning.

This style of work was sustainable only by the relatively young and fit. During our stay two distinguished general physicians came to work in Botswana at or near their retiring age, and both had myocardial infarcts soon after their arrival. Good physical health is an obvious prerequisite for anyone contemplating a period in a developing country.

For a time I was the only psychiatrist in the country. My predecessor left 24 hours after I arrived, and the Government was insistent that I take up my duties straight away. A period of adjustment, adaption and language training would have been very helpful. Such a time is worth pushing for.

We stayed in Botswana for just over two and a half years. Aid contracts are usually for two or two and a half years minimum period. It is not really worth spending the large sums of money involved in sending relatively senior professionals abroad for periods of less than two years. Cynically, most people say it takes six months to settle in, you work for a year, and then spend six months thinking about what to do next. We had initially intended to go away for just a year, but in the end we felt guilty that we left Botswana as soon as we did. Certainly 12 months would have been too short a time to do anything useful.

\section{Coming back}

It was clear to me from the start that I had to look on working in Botswana as an experience in itself and that there was no point thinking about it in career terms. Of course, that did not stop me intermittenty becoming pre-occupied with what I would do when I left.

As part of a cost-cutting exercise the British Government scrapped its advisory service for aid personnel returning from overseas. They sent round a rather depressing booklet by way of compensation which made the point that experience overseas is neutral, if not actually disadvantageous, in career terms. The experience of working in a developing country seems so far removed from every day working life in Britain, that it is hard for colleagues to make any connection with it. When investigating consultant posts on my return I found people were con- cerned only with what I had done up to the time I had left and that I seemed professionally to be at the same point that I had been before I went away. As a general guideline the more experience one has, the easier the work is abroad, and the easier the return. It is unlikely that experience in a developing country would routinely count towards higher professional training.

In the event the cultural shock of return was considerably softened by the Wellcome Trust. I had been able to do some research whilst in Botswana, and I had applied to the Wellcome for support to get it organized. They were wonderful. One of the senior staff said over the phone to me, 'English doctors are so stuffy and boring, they hate people going away and doing anything different. How can we help you?' They then gave me an eight-month grant, which enabled me to work on my data and 're-enter' gradually.

\section{Conclusions}

The real danger of spending a prolonged period working in a developing country is that the experience may be so intense that it changes one in unpredictable ways. Plans made before leaving become less relevant on return.

There are few opportunities for psychiatrists in the developed world to work on the large canvas afforded by single-handed practice in a country of one million people. Anybody contemplating such a move should be aware that the professional demands made on him or her will be extremely varied and the broader one's training, the better. ${ }^{3}$ I found my experience by turn exhilarating, fascinating and frustrating and sometimes all three at once. I certainly valued it enormously, and suspect that many others who enjoy a challenge would do so as well. In Botswana, emotions are experienced in the heart and I fear that I may have left a part of mine in Africa.

\section{ACKNOWLEDGEMENTS}

I would like to thank Professor Arthur Crisp and St George's District Division of Psychiatry for their continued support and encouragement.

\section{REFERENCES}

IBEN-Tovim, D. I. \& KUndU, P. (1982) Integration of psychiatric care with primary health care. Lancet, H, 757.

2 (1983) A psychiatric service to the remote areas of Botswana. British Journal of Psychiatry, 142, 199-203.

1_ (1983) Development psychiatry: The Botswana model. In Psychiatry in Developing Countries (ed. Stephen Brown). London: Gaskell.

\section{Interdisciplinary Association of Mental Health Workers}

This new association has been set up to promote active schemes, policies and research which will help professionals engaged in health and social service practice to reach a better understanding of each other's contributions to the care of the psychologically distressed. Further information is available from Chris Born (Publicity Convener) or Peter Huxley (Secretary), Interdisciplinary Association of Mental Health Workers, 126 Albert Street, London NW1.

\section{Computer Program on the MHA 1983}

Dr T. F. Packer (17 Lily Crescent, Jesmond, Newcastle upon Tyne) writes: I have compiled a computer program which contains 100 questions on the Mental Health Act 1983. The program is called 'Testcards' and runs on a BBC Model B microcomputer. It uses coloured text and optional sound to pose a randomly selected set of questions. The score of correct answers is given at the end. Copies of this program on a compact cassette are available at a cost of $£ 1$ to cover tape, post and packing. 